\title{
A New Insight to the Persis Kings (Frataraka)
}

\author{
Amir Amiri Nezhad \\ Department of Archaeology, Faculty of Literature and Humanities, University of Sistan and Baluchestan, Zahedan, Iran \\ Email address: \\ Amiramiri12@yahoo.com

\section{To cite this article:} \\ Amir AmiriNezhad. A New Insight to the Persis Kings (Frataraka). International Journal of Archaeology. Vol. 6, No. 1, 2018 , pp. $37-45$. \\ doi: 10.11648/j.ija.20180601.15
}

Received: April 21, 2018; Accepted: May 5, 2018; Published: September 15, 2018

\begin{abstract}
History of Persia after the Alexander, which is called Hellenism, was written by local available resources to revive the history of local governments during Seleucids and Arsacids, especially the Persislocal government. No doubt the most useful and documented local resources are the coins minted by the Persis local kings which shows the Pars Province had internal autonomy for a while ruled by local governors. The present study covers a period from 300 B.C. until 130 B.C. in which reviewing the first group of coins of Persis kings well known as Frataraka. It carried out as a field and library research gathered and reviewed coins of Persis kings preserved at some museums such as Bank Sepah Museum, Ancient Iran Museum, Iran Money Museum and some official numismatic catalogues. No doubt, these coins contain some special political and religious symbols rooted in their past. The present study is aimed to review the historical events within the aforementioned period relied on knowledge of numismatics, which carried out by descriptive - analytical method in order to represent an exact history of Persis local government (Frataraka).
\end{abstract}

Keywords: Coin, Frataraka, Persis, Local Government

\section{Introduction}

As the Seleucids gained power in Iran, independent and semi-independent governments also took charge from all corners of Iran and were in power until the end of Parthian period. One of the most important semi-independent governments came out of ashes of the Achaemeniad Empire was the local government of Pars (Persis). It had three local governors at three periods, of which the first was Frataraka. Bagadat (Bagdad) was the first king of the group back then who minted at the third century B.C. These coins minted at four Dirham and one Dirham. The last king of the group was Autophradates.

There have been various coins discovered from this local government which their motifs reflex the religious and political thoughts of Persis kings (Frataraka). These thoughts initiated the governmental ideology are very important as they reflex the Persian culture and society. It goes without saying that a coin is one of the most important documents and authentic references of cultural findings and it has valuable information in terms of absolute chronology (due to the inscription, date on minting, kings face and finding succession of kings), and in terms of cultural, artistic and belief (with the carved motifs), in terms of economic (material and size) and in terms of style (regional and transregional communications).

As studies on Frataraka coinage categorized into the arts of Frataraka, sometimes individually, and often introducing kings and their figures on the coins, the present study, in library method, reviewed the hidden concepts on the motifs at both faces of coins minted with political and religious orientations; so first the given coins collected from the Iranian Money Museum, Iranian National Museum (Iranian Ancient), Bank Sepah Museum and official numismatics catalogues and then examined and analyzed using a historical approach (historical events in that period) and archeological data (Frataraka architecture and arts) in order to revive the history of Persis local government exactly under the ruling of Frataraka kings (300 B.C. -130 B.C.).

\section{Bibliography of Frataraka Coins}

Frataraka coins discovered in archaeological excavations dates back to the nineteenth century and early twentieth century by which various coins were discovered from Khuzestan, and around Persepolis and Istakhr in Fars Province [1]. Joseph Pellerin (1767), a French scientist, 
introduced the first Frataraka coins [2] attributed to the Sassanid era due to having Aramic inscriptions [3]. However, Allotte de la Fuye (1906) first classified the Frataraka coins, and George Hill (1922) published the first journal. Hill introduced the Frataraka coins in four groups and named the first period as the Frataraka coins are thought to be minted from Bagadat to Autophradates. He then determines the second period with the name changed as Malka. Simultaneously with Hill's work, Jaques DeMorgan published a book on Middle East coins in which there were some Frataraka coins in the catalogue [4]. The examination procedure stopped for Frataraka numismatic and it was not until 1937 that some limited catalogues published on Frataraka coins [5].

Mitchiner exhibited a set of Frataraka coins in 1978 by which underlined the famous notes of Robert Göbl published in 1983. The British David Sellwood (1983) also helped the study with the notes on Frataraka coins in the Cambridge History of Iran. Dr. Michael Alram (1986), Professor at the University of Vienna, even went further from the previous researchers and so far most of Frataraka numismatic carried out based on his research. Alram (1986), in his new book which was the result of fine classification of Frataraka coins based on artistic criteria, presents a new classification compare with the works of Hill and DeMorgan. It led Wiesehöfer (1994) to write a masterpiece on history of Frataraka in "Dark Ages" in which he tries to have a historical view on the region at this period. Later in 2009, the book translated into Persian by Hooshang Sadeghi. With more extensive studies on Frataraka coins in 2008, new theories come on the scene such as Oliver Hoover (2008), based on his research, calls Bagadat at the third Frataraka not the first one and he believes Artaxerxes has been the first Frataraka. However, Vesta Sarkhosh (2010)1 assumed that Whwbrz and Bagadat were rival kings and she considered their overminted coins as the proof. Unfortunately, since 2010 there has not been any comprehensive research published like Alram, Hoover and Vesta Sarkhosh did before.

\section{Political History of Frataraka}

According to the historical documents, Alexander of Macedon, in his attack on Iran and its capture, implied the most severe blows to the Persian body and suppressed any opposition and riot against him in the area $[6,7,8]$. After the death of Alexander about 323 B.C., his commanders started fighting each other well known as Diadochoi. There was a fight between two famous commanders of Alexander (Eumenes and one-eyed Antigone) in Susiana and Media in which Antigone won and minted coins in Susa in 316-318 B.C. [9]. Peucestas, one of famous Alexander commander, was the Persis ruler back then who adopted soft policy towards the natives, with the Persis background. He

1 - Sarkhosh C.V., 2010. "The Frataraka Coins of Persis: Bridging the Gap between Achaemenid and Sasanian Persia," in: J. Curtis and St. J.Simpson (eds.), World of Achaemenid Persia, London: I. B. Tauris, pp. 379-396. empowered Persis authorities and shared his power with them [10]. Strabo suggests that Persia was tributary to Macedonia [11]. Seleucus, in the Western parts of the empire, conquered Mesopotamia in 312 B.C. and fought against Antigone in in Ipsos battle in 304 B.C. and he managed to win the battle, conquered Persia, and established Seleucid dynasty. He minted coins in 300 B.C. in Susa and Pasargadae [12]. These events reflect the removal of Peucestas in Persis. Though it is not clear when exactly Persis tried to revive its power, there is little information available on relationships between Seleucus and Antiochus I with Persis. It can be said that, because of the marriage between Seleucus and Apameh, daughter of Spitamenes, the relationships can be considered good, it could put the Seleucus legitimacy among the people in danger as there was no Persian race sensitivity [13]. Seleucus in 281 B.C. put his son Antiochus as the ruler of Asia and he went to Macedonia. Antiochus set up so many cities and colonies and the remains of Hellenistic pottery in Takht Hill and Pasargadae and Zahak Hill enclosure in South West of Shiraz show that the Seleucids established colonies in the region [1]. Antiochus I was killed in 261 B.C. in Sardis while suppressing a local riot [14]. Antiochus II also known as Theus (God) sat on the throne as his father successor. He then was poisoned to death by his wife Laodice to make Seleucus II, also known as Callinicos (lustrous conqueror), sat on the throne.

What Herzfeld wrote about the history of Persis shows that the Persis kings established the Frataraka government in 300 B.C. But Herzfeld was not sure about the exact date, as he mentioned the date to be 150 B.C. Based on the discovered Frataraka coins by Herzfeld, Newell suggests the relative independence date to be 280 B.C. He adds the successors of Alexander went into war to seize power and the Frataraka seized the opportunity to mint coins and could keep its semiindependence rule before the Molon uprising. Hill suggests the first Frataraka that is Bagadat coin minted in 250 B.C. [15]. However, Koch believes that Bagadat has carried out his nationalist movement in the half of third century B.C. [16]. Nevertheless, he does not regard it as a complete independence. DeMorgan and Stiehl, based on the coins from the Frataraka, suggest it to be 220 B.C. [17]. Therefore, he has considered the Persian massacre coincided with the emergence of Bagadat and it was after Antiochus that he has minted coins. Concluding the theories discussed, it was not possible for the nationalism of Frataraka to be occurred before the time of Seleucus I, as the historical books suggest there were the Macedonian rulers of Persis before 312 B.C. Schmitt believes that Persis has been ruled by the great Antiochus' supporters but he reveals no new evidence for confirmation [18].

The present research, with the historical events in this period, suggests that Bagadat could not mint the first Persis coins before the killing of Antiochus I in 261 B.C., on the other hand, during the post-Antiochus I that the Persian natives had military and royal positions (it was common to empower the Persian natives since Peucestas) seized the opportunity and controlled the region during the reign of 
Antiochus II and they announced independency and minted coins due to the weakness of the Seleucid kings and civil wars during the reign of Seleucus II and III (246 B.C - 223 B.C.). Historical events especially the Ptolemy III's attack to Persis, Media and Susa and weakness of Seleucid government and Parthian revolt in East indicate that there was local government in Persis. In other words, just saying that Bagadat minted coins in 220 B.C. could not have historical support as the historical books mention Iskandar, he was the ruler of Persis who led a riot against Antiochus III helped by his brother and ruler of Median ruler Molon.

The king of Egypt, Ptolemy III (238 B.C.) fought against the Seleucus II, passed the Euphrates and conquered Mesopotamia, Babylon, Susa, Persepolis (Pars) and Media. Arsaces seized the opportunity to defeat Andragoras and claimed the throne. Seleucus managed to compromise with Ptolemy and went eastward about 238-9 B.C. and could not do much deal and Tiridates established Parthian dynasty building the city of Dara or Darium [19]. Antiochus III, also known as the Great Antiochus, rose to power in 223 B.C. In his reign, Molon, the Median ruler helped by his brother Iskandar, the Persis ruler, run riot and took the throne. Wiesehofer recalled the riot to be in 205 B.C. [20]. He easily conquered Babylon, Eritrea Sea bank (Persian Gulf and Oman Sea), Susa (excepting Susa enclosure) and nearly Mesopotamia. The king alerted and he personally intervened to suppress Molon and managed to defeat him near the city of Apolloniatis. The uprising shows that the Seleucids have controlled Persis years before 220 B.C. Afterwards, Antiochus went eastward and convinced Arsaces to surrender and made them tributary to himself. However, war against the Romans warned the end of Antiochus power. In a war about 190 B.C. in Magnesia (Anatoly), Antiochus defeated by the Romans and accepted the heavy terms of Apame peace treaty (188 B.C.). To pay the tribute to the Romans, Antiochus marched out to Susa and Persis in 187 B.C. He intended to loot the Bell Temple in Elymais [21]. However, he confronted with the resistance of Susan natives. It predisposed the riots of Susa and Ajapir (Izeh) which ultimately Elymaian established a local government in 147 B.C. led by Kamnaskires.

The weakness of Antiochus III since 190 B.C. until his attack in 187 B.C. and the start of civil revolts in Susa made a proper ground for Artaxerxes I to mint coins in Persis. According to the historical events, his coins could not have been minted during the authority of Antiochus III (before 190 B.C.). At the other hand, years after 175 B.C. are the authority of the Antiochus IV that the historical books show he conquered Armenia, Media and the Persian Gulf shores. This charge of Antiochus IV occurred before 162 B.C. Then with the historical events the minting date of Artaxeres I coins can be considered about 190 B.C. to 175 B.C. [22].

Antiochus IV (Epiphanies) who was a competent king sat on the throne in 175 B.C. He organized the ruling financial affairs; then charged his army across the Euphrates to raise the taxes. He first came to Armenia, though they apparently were belong to the new king of Seleucid dynasty but actually refused to obey the king's orders. Antiochus charged to the Persian Gulf shores to lead Persis once he conquered Armenia and Media. This charge of Seleucid king indicates that the Seleucids had not ruled Persis during 187 B.C. to 175 B.C. Antiochus IV attacked the Temple of Nanaya in Elymais about 162 B.C. but his charge did not work and the settlers took up guns and prevented the desecration to the temple. Therefore, the Seleucid king forced to withdraw empty handed and went to Persis. He got sick along the way and passed away in the city of Gabiana. As Polybius, Diodorus and Appiano quoted, Antiochus passed away due to a deadly disease reveled by the heaven [23]. Death of Antiochus started the fall of Seleucids so that civil wars and royal disagreements were at their peak with Antiochus V sat on the throne, it coincided with the minting of first Elymais local government coins in Ayapir and Susa.

The historical books illustrate the years after 162 B.C. full of chaos and massacre in territories ruled by the Seleucids. Demetrius killed Antiochus IV brutally, and Alexander Ballas killed Demetrius in Syria in 150 B.C. This period (162 B.C - 150 B.C.) is the most logical time for minting the Vahuburze coins due to the excessive weakness of Seleucid kings and their attention to the western lands, as they could not mint coins before 162 B.C. due to the authority of Antiochus IV. At the other hand, in the years after 150 B.C., Alexander Ballas' attack to Susa and Persis has been mentioned in the historical books and then he conquered Persis and Elymais. Therefore, it is more likely that Vahuburze coins were minted during 162 B.C. -150 B.C.

Polianus quoted in the Seventh book that the Macedoniam ruler of Persis thought of killing 3000 Persians. He gathered and lured them with some excuses rounded by an army of 300 cavalries and 3000 heavy infantries and massacred them. Polianus added Vahuburze scattered 3000 Greek soldiers among the Persian people and put them in the Persian houses and ordered to massacre them overnight [13].

The present research believes that this massacre by the Seleucids could only happen during Alexander Ballas reign as the historical books and minted coins by the king in Susa indicate that Alexander Ballas conquered Susa once again and subjugated the Elymais. It occurred during 150 B.C. 147 B.C. as Demetrius II helped by the Egyptian king (Ptolemy Moheb al-Om) started a long battle against Alexander Ballas around Western parts of Seleucid empire in 147 B.C. Departure of Alexander Ballas to the West parts put the East parts in turmoil. In these days, Elymais established a local government in which Kamnaskires minted coins as the leader. Mehrdad charged his army to the North and West parts of Iran and Autophradates I become the Persis ruler and his coins could be minted from 147 B.C. to 129 B.C. onward as before these days the dominance of Alexander Ballas on East and North parts of Persian Gulf is final.

The Parthian Mehrdad marched to the Media in 147-8 B.C. and he conquered it about 144 B.C. and seized the Seleucid with an attack on Babylon in 141 B.C., so that the dated coins of Mehrdad minted in 138-139 B.C. and 139-140 B.C. in Seleucid confirmed the event. Mehrdad retruned to 
Hirkani after the battle ended. About 140 B.C. due to the requests by Macedonians and Greeks settled at the Upper Satrap such as Babylon for Demetrius II in Syria and, at the other hand, disaffection of Demetrius to stay in Syria led him to think to retake the lost lands. Demetrius charged to the East and entering Mesopotamia passed Babylon. He won battles against the Parthian. The Persian led by Autophradates I hoped to gain its full independency and rejecting tribute to the new rulers, the Iranian Najd (Parthian) came to help Demetrius II to battle the Parthian. However, he was unlucky in the decisive and final battle about 131 B.C. The Parthian general charged at him with some tricks, routed his troops and captured the Seleucid king. Then he wandered the king around the Parthian cities and sent him to Hirkani with Mehrdad. Mehrdad treated Demetrius well, engaged his daughter Roodgooneh to him and sent him to Gorgan. Mehrdad attacked the local governments due to their collaboration with Demetrius II and the Khong-e-Noroozi stone in Malmir plain recorded the victory of Mehrdad over Elymais as it says "Mehrdad the King of Kings" [24]. At the other hand, his minted coins have found in Susa but the Parthian king kept the local rulers in their local governments $[25,26]$.

Antiochus VII Sidetes in 129-130 B.C. went into war with the Parthian outreaching them under the pretext of freeing his brother [27]. Houghton [28] believes that the Parthian controlled Susa until 130 B.C. but Antiochus VII conquered it for one year. During his war with the Parthian, the Seleucid army ordered by Antiochus deployed at Media and Persis for winter. The deployment and food shortage led the Seleucid army to suppress the Median and Persian natives. If we refer to the Ploianus report once again, it would justify the massacre of Seleucid army carried out to revenge the killings of 3000 Persian army and it is more likely done in Autophradates I, as the historical books and events suggest the revenge carried out by the Whwbrz successors (e.g. Autophradates). The Seleucid army defeated in 129 B.C. and Antiochus committed suicide because he did not bear the defeat. Once Farhad II defeated Antiochus, we witnessed coins under the name of Farhad II in Susa and Elymais. It was after the war that the Scythians battle with the Parthian in the West area and the Parthian king forced to confront them at that area. The Parthian army failed to do anything against the Scythians and the Parthian king killed in the battle. Autophradates announced full independence with the weak Parthian government and lack of Seleucid power in the region, so that Fravahr symbol as monarchy on Autophradates coins confirms the event.

Therefore, it is more likely to believe that the first three kings of Frataraka (Bagadat, Artaxerxes and Whwbrz) had semi-independent government. Struggling for independence paid for during Autophradates I and the full independence was in place until the end of Autophradates government. Starting the second period of Persis kings during the Autophradates II, Persis kept running as semi-independent state under the Parthian rulers [29]. At this time, the new rulers took power in Persis who chose the title of Melaka on their coins that were essentially different with the previous coins and it perhaps represents the new dynasty other than the Frataraka [23].

\section{Frataraka Coins}

Bagadat coins have minted in two different sets. The first set (Figure 1) is considerably different from the other Frataraka coins in type and design. The second set is more like other coins of Frataraka kings and Alram [30] believes that this set is newer than the coins of the current king (Figure 2).
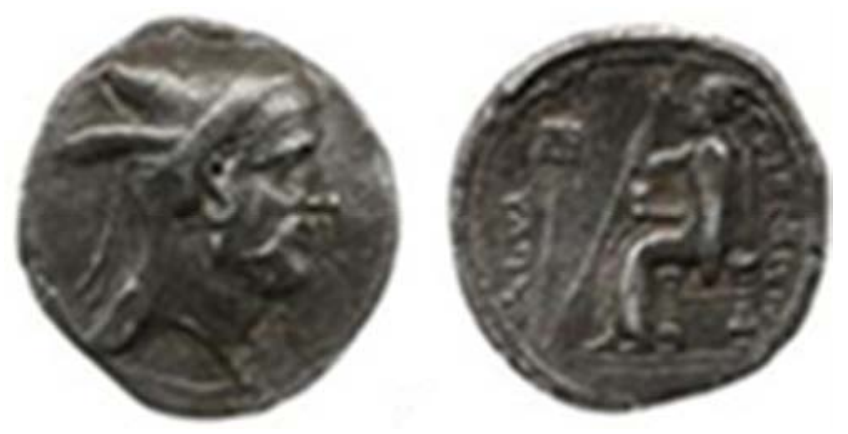

Figure 1. Bagadat [60]
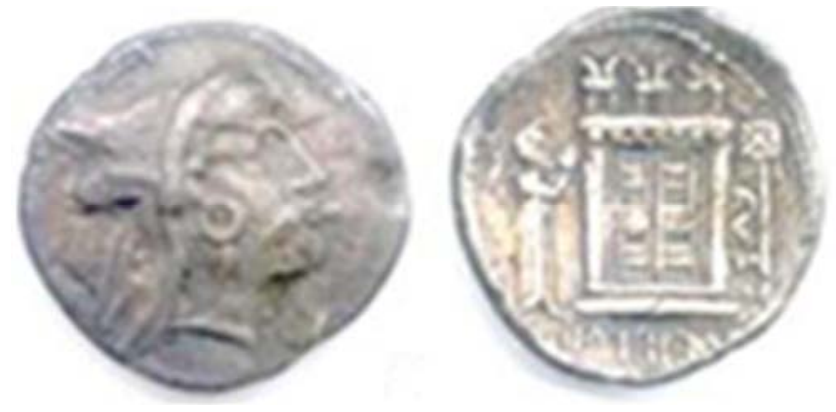

Figure 2. Bagadat. NO 10873 [61].

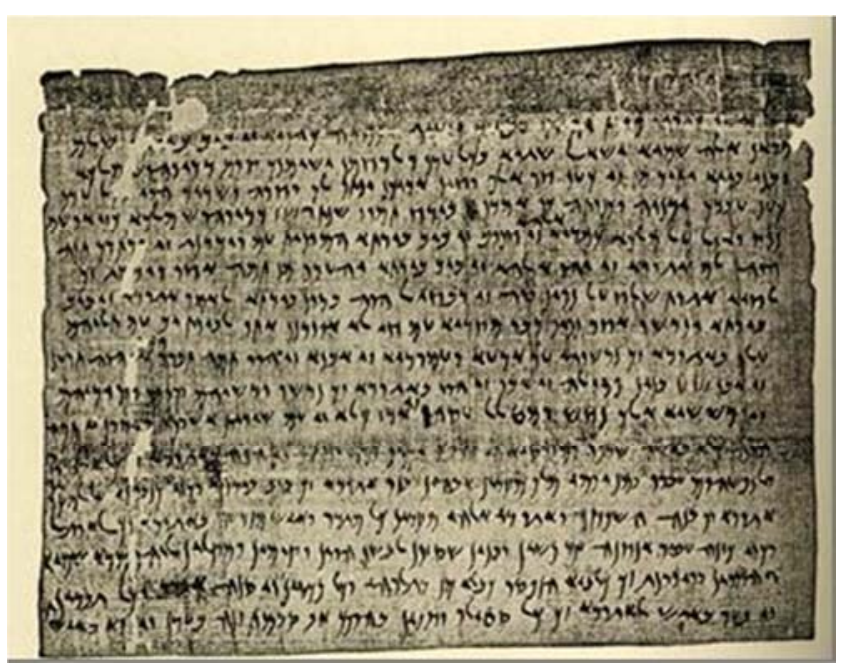

Figure 3. The Aramaic Papyri of Elephantine [31].

The Bagadat coins introduces the king as they said "bgdtprtrk' $Z Y$ ' $L H Y$ ' BR bgwrt" (Bagadat, a heavenly Frataraka, the son of Bgwrt). Naster has carried out some 
research on "Frataraka" on Bagadat coins [31]. He carried out a comprehensive critical analysis on words "Fratakara", "Fratadara" and "Frataraka", so he introduces "Fratakara" as "Someone who lit the fire", "Fratadara" as "Someone who carries the fire" and "Frataraka" as "Commander or governor". He believes that the first two words could not be right as titles of rulers due to the excessive attachment to religion but the third word seen on papyrus text (Figure 3) since the Achaemenid era in Egypt, which was used to call the Parthian ruler and Wiesehofer also confirms it. Ito[32], based on Naster studies, reviewed the Papyrus documents comprehensively with Frataraka title and he interprets the titleholder in Egypt as "Pioneer, governor, deputy, representative ..." Accordingly, Henning and Hinz [33] translated Frataraka as "Commander" and they do not believe it is a royal title and they mention it more as "Vassal". In Aramaic texts, Elephantine Frataraka is someone who ruled the completely South areas of Egypt and he was seen higher rank from the army commander [2]. Another important word seen on all Frataraka coins is $\mathrm{ZY}$ ' $\mathrm{LHY}$ ' meaning "From the Lords". Toraj Daryaee [34] suggests that the word originated from Seleucids and translates it as $\theta \varepsilon \circ \pi \alpha$ $\tau \omega \rho$ "with divine race". The word Bagadat has also old history and Koch [16] believes that its ancient Persian form has been used repeatedly in Achaemenid inscriptions. The motifs on the first set of Bagadat coins are different from other coins. In other words, at the back of the first set of Bagadat coins king sat on the throne to his left profile holding a long royal stick with a lotus flower [35]. Some researchers such as Soodavar [36], suggest the lotus flower as divine charisma in Achaemenid era. The scene resembles in many aspects the high reliefs of Achaemenid kings in Persepolis (Figure 4), and maybe the king deliberately thought of linking with the Achaemenid kings. At the back of the second set of Bagadat coins there are three motifs minted on all the Frataraka coins. At the back of the Frataraka coins, the king is standing praying in front of a holy structure on which there are three objects. In front side, there is a two wings door between two vertical wooden beams and each wing divided into four frames. At upper side, there is a row of circular dents thought to be are the head of Farasps (big beams). On the flat outer surface, there are three square objects with a shelf-like anterior and the upper line is a little wider and thicker on which there are two outward crooked horns [37]. Over the holy structure, there are three big flames, possibly resembling the three Iranian classes (leaders, warriors and artisans). Potts [3] believes that the Persis kings necessarily did not know the application of building and only used it on their coins as a symbol of power and glory of their ancestors. Most researchers suggest the holy structure as the Kaaba of Zoroaster or similar figures (Figure 5).

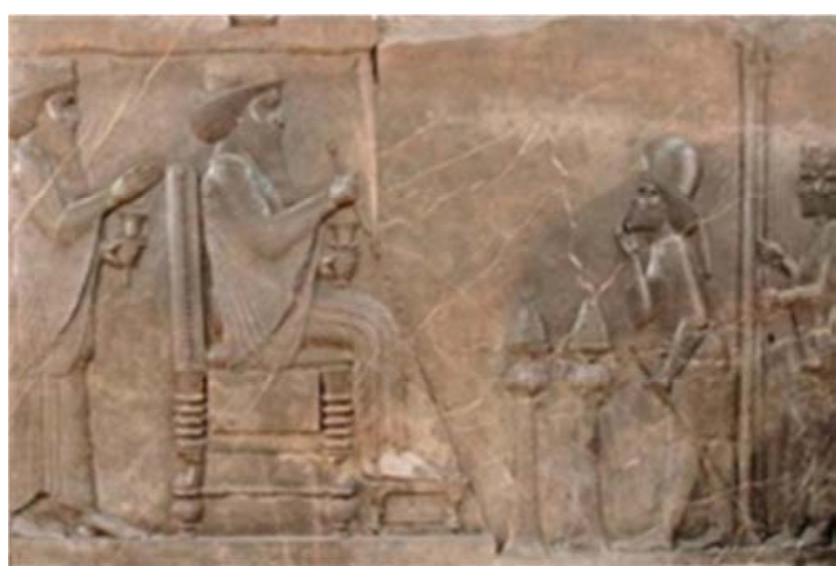

Figure 4. Achaemenid reliefs [62].
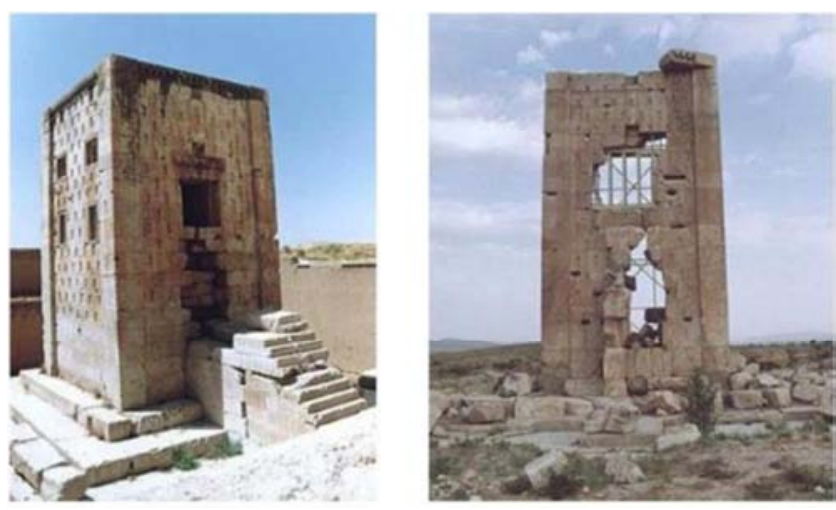

Figure 5. Kaaba of Zoroaster, Solomon Prison [62].

There are different assumptions for the structure of Kaaba of Zoroaster [38]. Erdman [39] suggests the structure identical to the motifs on Frataraka coins. Nevertheless, Stronach [40] describes the structure as a sample of postAchaemenid fire temples. However, Dr Shahbazi [41] suggests the structure as the Fire Temple of Persepolis platform. The only prominent architectural work of Frataraka is a building discovered by Herzfeld [42] in 1923 in $300 \mathrm{~m}$ Northwest of Persepolis platform and it became known as the Temple of Frataraka (Figure 6).

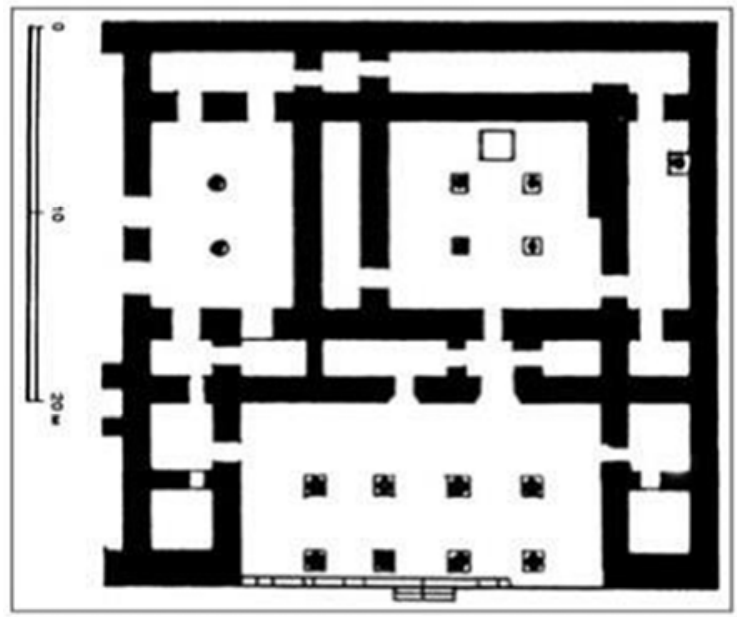

Figure 6. the Temple of Frataraka [43]. 
Shenkar [43] describes the reason of its attribution to the Frataraka kings as it is not a part of Persepolis royal set and it has three bases of pillar of which two bases reused after the destruction of platform and the third base is cubic which was not common in architecture of Persepolis. Tilia [44] suggests that the Frataraka constructed monuments in Persepolis. Roaf [45] following Tilia research, guesses that a Frataraka ruler possibly lived at the post-Achaemenid residence located at the south corner of Persepolis platform. However, the most important reason is a Frataraka motif, which clearly resembles the worshiper at the back of Frataraka coins (Figure 7).

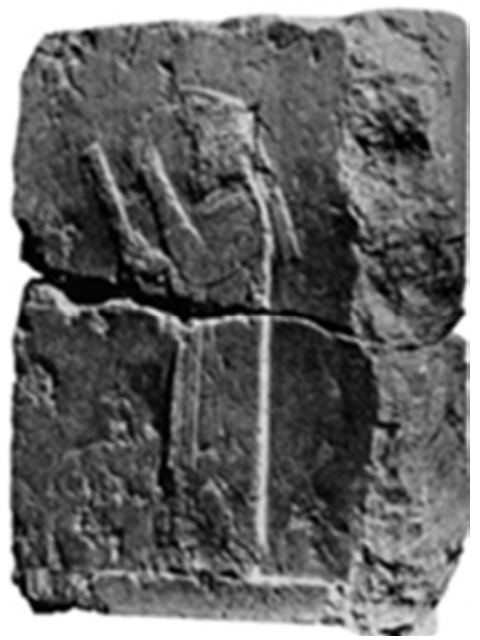

Figure 7. Frataraka reliefs, pl. III: b [46].

The motif of worshiper is on every Frataraka coin, so that the Frataraka king personally depicts the worshiper in the embodiment of a big cleric. The worshiper wore a satrap hat and raised his hands for respect praying standing in front of the holy structure (Kaaba of Zoroaster). Debevoise [46] compares the motif of worshiper on Frataraka coins and the motif of Frataraka kings from Persepolis with the motif of Dukkan-e-Daud in Sarpol-e Zahab (Figure 8) and estimates it dates back to 150 B.C. -250 B.C.

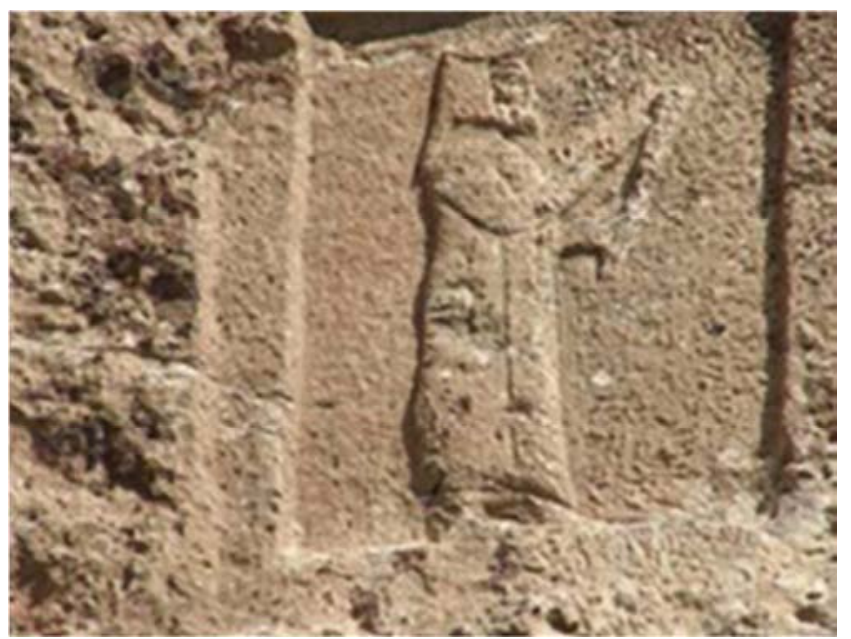

Figure 8. Dokan Davood Inscription [62].
The satrap hat of worshiper, which is on Frataraka king's head and minted on post-Bagadat coins, is a typical felt hat protruding forehead and covering neck and face which covers all the lower face. It protects the sacred fire from pollution of breath. The edges pull up a little, during religious ceremonies to cover the mouth. However, all parts of the hat are integrated. The hat represents all the kings of Frataraka, which completely resembles the hat on Achaemenid coins. The satrap hat motif minted on four-dirham coins of Tisafern satrap of Lydia and Caria at late fifth century B.C. in Asia Minor (Figure 9).
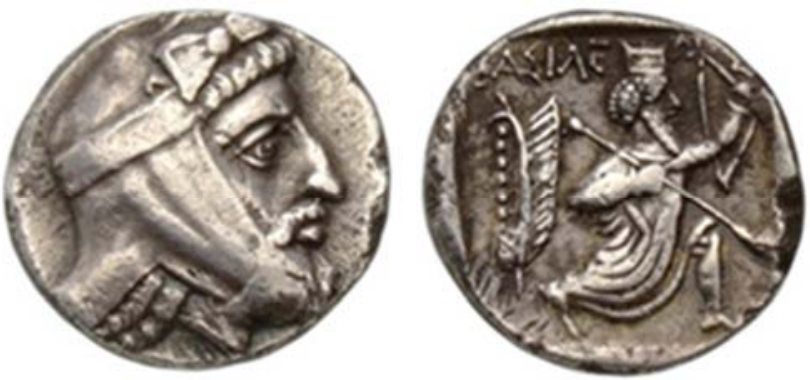

Figure 9. the king sent a nobleman named Tissaphernes to Lydia [2].

Hall [47] believes that people wore the hat with the lowered edges at early Mogan era in Achaemenid and Sassanid eras. At the right side of the holy structure behind the Frataraka coins, there is a flag motif, which is a characteristic of Frataraka coins. The flag is a curtain or plate on top of a spear and a there is a cross divides the banner into four parts from two opposite corners in which there is a circle carved within each part. There are four strips hanging pairwise from two sides of spear underneath the banner that each seems ends to a ball. In Ferdowsi's Shahnameh the strips colored in red, yellow, violet and blue [48]. The motif is a symbol of Achaemenid flags decorated with stars and tassels [49] and minted on coins of Darius III [48].

The coins of Artaxerxes I are similar to the second set of Bagadat coins on which the king standing praying in front of the holy structure and behind the coin the king introduces as "Artaxerxes, a divine Frataraka (The Persian boy or Persian Frataraka?)" "rhštr (y)/ prtrk' ZY'LHY'/ br/(prs)" (Figure $10)$.

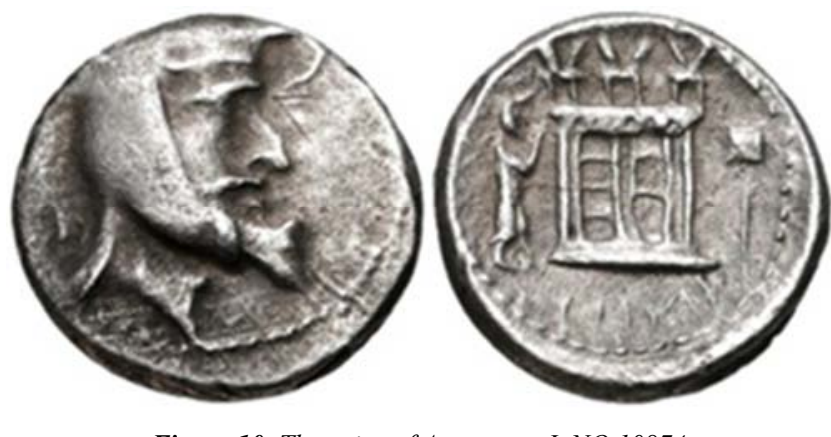

Figure 10. The coins of Artaxerxes I, NO 10874.

The coins of Oborzos/Vahbarz is similar to the coins of Artaxerxes on which the king depicted with a special hat and 
at the back the king standing praying in front of the holy structure as it says in Aramaic "Vahbarz, a divine Frataraka" (The Persian boy or Persian Frataraka?)" (Figure 11).

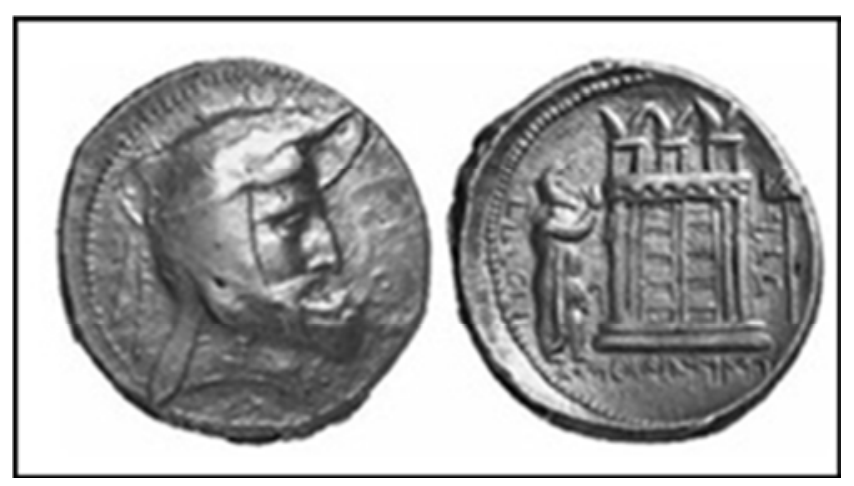

Figure 11. The coins of Vahbarz [63].

Autophradates is the last king of the first Persis rulers. The coins introduce the king as they say "Autophradates, the divine Frataraka" (wtprdt/ prtrk' ZY 'LHY'/br) (Figure 12).
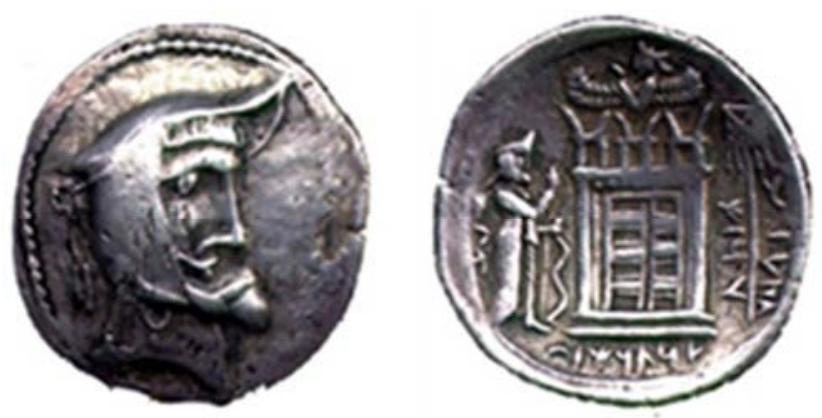

Figure 12. The coins of Autophradates I/ Vadfradad I, NO 10875 [61].

At the back of coin significant changes have occurred, on which the king is standing with his hands rising up toward the holy structure and holding a bow in his left hand. The bow has double sacred states of which one end touches the ground. Dr Shahbazi describes the bow as it is a Achaemenid warfare about one meter long. However, most researchers such as Coleman Hura (1984), Richard Frye [50], Sir Percy Sykes [51] and Ibrahim Poordavud [52] described the Achaemenid bow as long and big and did not mentioned the exact size. Bows (almost similar to Frataraka bows) commonly used at the first period of Darius I and then it minted as a military tool and a symbol of power in the motifs attributed to the Artaxerxes I [53]. For the first time the bow depicted at the back of Autophradates I coins and the similar bow carved as motif at the Ghizghapan Catacomb in Iraqi Kurdistan. Girshman and VonGall [54] suggest the bow in Ghizghapan Catacomb represents the mortal ruler. Another important role appeared for the first time on Frataraka coins is the Farvahr motif. It was introduced in Egypt and resembled the Horus God and then later resembled at the north of Mesopotamia resembled the God of Assyria [55]. As a result, conquering Babylon, the symbol came in the Iranian culture, and Farvahr or the winged man became the symbol of Ahoura Mazda and they replaced it for the fire of temples so that the symbol used extensively [47]. Avesta describes the symbol as the Holy Spirit and savior of the world, which exists everywhere, it is a symbol of spiritual power and supporter of Iranian kings, and it is placed over the head of king [56]. Farvahr is an internal sacred force appeared as a shining man with two wings and rings and it is an ancient national Iranian symbol [57]. Most researchers of Ancient Iran suggest the Farvahr or the winged man as the symbol of Ahiura Mazda [58, 59, 47]. The motif considered one of the important reasons in full independence of Persis during Autophradates ruling era, Calmeyer and Shahbazi believe that the crown of winged man is different from the king's hat as the former is typically from the Achaemenid crenate crowns, though the king wore a satrap hat. The image at the back of Autophradates I coins represents the motif of the Darius I at Naqsh-e Rustam monument in which the trinity of the king praying holding a bow in his hand, a fire altar and the winged man has been depicted (Figure 13).

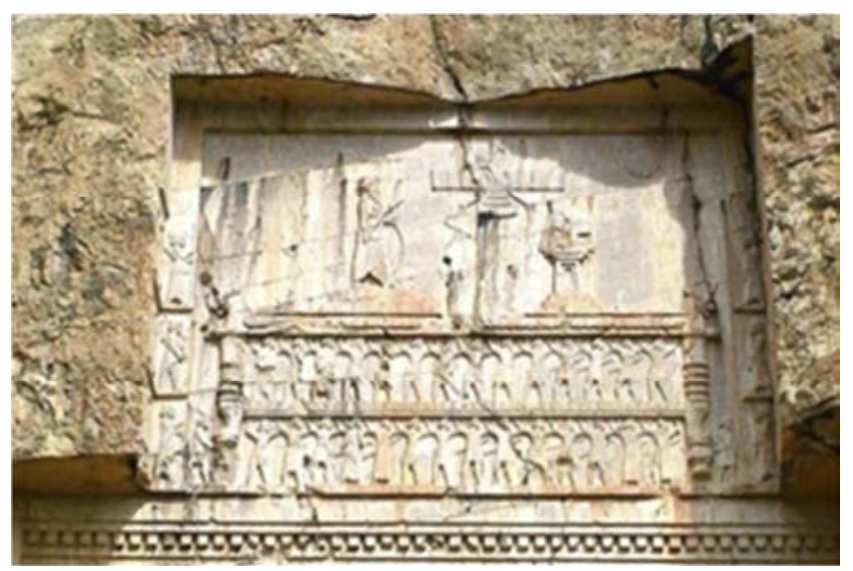

Figure 13. Tomb of Darius the Great at Naqsh-i Rustam [62]

\section{Conclusions}

The Frataraka were the local kings of Persis, which preserved with full awareness of traditions and political and religious symbols used in Achaemenid Empire and transferred them to the next generation (Sassanid) in more evolved formation to introduce the religious political system in new harmony mould in Sassanid world leadership system. The political religious symbols used in the Frataraka coins are similar in meaning and concept. The Bagadat coins were the first Persis coins. They minted in two sets. The throne symbols with lotus in king's hand like the motif of Great Darius in Persepolis, as it seems the Persis king (Bagadat) wants to remind his power to the foreigners with this image and as the holy structure, flag and his motif as a worshiper tries to present his legitimation among the people with his originality and also introduce himself with the flag as a follower of powerful Achaemenid Empire army and as a follower of past religion with the holy structure and worshiper. These motifs are clearly depicted in Ghizghapan, Dukkan-e-Daud and Eshaghvand catacombs. Therefore, the king presented himself to the foreigners and remind his legitimation to the natives. Artaxerxes became the king after 
Bagadat and his coins are similar to the second set of Bagadat coins. These two kings could establish a semiindependence government in Persis. The third king who called himself a Frataraka king was Vahbarz and as it is said, the most researchers suggest that in his reign Persis ruled completely independent. It is not acceptable according to the historical stories and the wars between Seleucid and Parthian kings. His successor was Autophradates I and based on the mentioned references and evidences in the paper, Persis had achieved a full independence during his reign and the Persis independence was all gone when his reign was over and the local government administered as semi-independence until Artaxerxes IV (the Sassanid Artaxerxes I) sat on the throne. We see new motifs on the Autophradates coins, which originated from xenophobia and independence thoughts. These motifs included the bow and Farvahr. As for the bow, the king presents himself as the absolute power of Persis and, as Achaemenid kings, he is capable of confronting enemy and preserve the holy land of Persepolis. For the Farvahr symbol, the king clearly manifests his power from neither people nor foreigners but Ahura Mazda as the powerful Achaemenid kings he also chosen by the Gods. The present study suggests that with the independence of Persis in Autophradates reign, new symbols and motifs reminding the absolute power of Achaemenid kings minted on coins and it was not possible unless there were no foreign power in control in Persis kingdom.

\section{References}

[1] Rezakhani, K. [2010]. "The 'Unbekannter König III' and the Coinage of Hellenistic and Arsacid Persis," International Journal of Iranian Studies (NIB) 15.

[2] Mohamadifar, Y., Khani, A. [2015]. Reconstructing the history of the Persian king during the Parthian, in: Journal of Archaeological Studies, 6(2), 149-165.

[3] Potts, D. T. [2007]. "Foundation houses, fire altars and Frataraka, interpreting the iconography of some postAchaemenid Persian Coin". Iranica antiqua 42, 271-300.

[4] DeMorgan, J. [1923]. Manuel de Numismatique Orientale de L'Antiquite et du Moyen Age, Paris: P. Geuthner.

[5] Kraay, C. M., Thompson, M., and Markholm, O. [1973]. an Inventory of Greek Coin Hoards, New York, NY: American Numismatic Society, pp. 256-259.

[6] Plutarch. [1990]. Lives of renowned men, translated by Reza Mashayekhi, Tehran.

[7] Olmstead, A. [1993]. The history of the Persian Empire, vol. 3, translated by Mohamad Moghaddam, Tehran.

[8] Wilken, O., Berza, U. [1997]. Alexander the Macedonian, vol. 1, translated by H. Afshar, Tehran.

[9] Bellinger, A. R. [1950]. An alexander hoard from Byblos, Berytus 10.

[10] Bevan, E. K. [1902]. The house of Seleucus. Vol. 1, London, Edward Arnold Publication.
[11] Edson, C. [1958]. Imperium Macedonicum: The Seleucid Empire and the literary evidence, Classical Philology 53 (3), 153-170.

[12] Jenkins, G. K. [1978]. Coins, in Stronach, D., Pasargadae, Oxford: Clarcndon Press.

[13] Wiesehöfer, J. [2009]. Fars under Seleucid and Parthian rule, in, V. S. Curtis and S. Stewart (eds.), The age of the Parthians, London, 37-49.

[14] Rajabi, P. [2002]. Lost Millennium, vol. 4, Tehran.

[15] Hill, G. F. [1967]. "The Coinage of the Ancient Persians", A Survey of Persian Art from Prehistoric Times to the Present, ed. A. U. Pope, vol. I, Tehran, London, New York, Tokyo.

[16] Koch, H. [1988]. "Herrscher in der Persis unter Seleukiden und Parthern", WO 19.

[17] Stiehl, R. [1959]. Chronologie der Fratadiira," EAltheim, Geschichte der Hunnen, Bd. I, Berlin, 1, 375-379, 1969.

[18] Schmitt, H. H. [1964]. Untersuchungen zur Geschichte Antiochos des Grossen und seiner Zeit, Wiesbaden.

[19] Gotschmidt, A. [2009]. History of Iran and its neighboring countries from the time of Alexander the Parthian extinction, translated by K. Jahandar, Tehran.

[20] Wiesehofer, J. [2007]. Die dunklenjahrhunderte der persis, translated by H. Sadeghi, Tehran.

[21] Holleaux, M. [1942]. Etudes d'epigraphie et d'histoire grecque, vol., Lagides et Seleucides, Paris.

[22] AmiriNezhad, A., Marofi, S., RahmanSetayesh, M. [2015]. Study on the Elymais and Fartaraka Coinage, Tehran.

[23] Kennedy Eddie, S. [2002]. The Cult of monarchy in the East, translated by F. Badra, Tehran.

[24] Saraf, M. [1993]. Elamite relief, Tehran.

[25] Kawami, T. S. [1987]. Monumental art of the Parthian period in Iran. Leiden, Acta Iranica, Troisième Série, V. XIII.

[26] Colledge, M. A. R. [1977]. Parthian art. New York, Ithaca.

[27] Meyer, E. [1969]. Blute und Niedergang, Der Hellenismus in Mittelasien, ed. F. Altheim/ J. Rehork, Aarmstadt.

[28] Houghton, A. [1983]. Coins of the Seleucid Empire from the Collection, New York: Ancient Coins in North American Collections 4 .

[29] Sellwood, D. [1994]. History of Iran, Cambridge, vol. 3, translated by hasan anosheh, Tehran.

[30] Alram, M. [1982]. Materialgrundlagen zu den iranischen Personennamen auf antiken Miinzen (Acharnenidische Satrapen; Persis; Sakas und Pahlavas), Phi! Diss (mschr), Wien.

[31] Naster, P. [1968]. Note d'épigraphie monétaire de Perside: fratakara, frataraka, ou fratadāra? Iranica Antiqua 8, 74-80.

[32] Ito, G. [1976]. Gathica XIV-XV, Orient, 47-66.

[33] Hinz, J. [1979]. Understanding the Iranian myths, translated B. farokhi, Tehran.

[34] Daryaee, T. [2010]. Ardaxsir and the Sasanians' rise to power. Anabasis 1, 236-255. 
[35] Alram, M. [1986]. Iranisches Personennamenbuch: Nomina Propria Iranica in Nummis, Wien: OeAW.

[36] Soodavar, A. [2004]. Ancient rituals divine charisma Kingdom, Tehran.

[37] Naster, P. [1970]. "Fire-Altar or Fire-Tower on the Coins of Persis", OlP, 1, 125-129.

[38] Schippmann, K. [1971]. Die iranischen Feuerheiligtiimer (Religionsgeschichtliche Versuche und Vorarbeiten, F), Berlin.

[39] Erdmann, K. [1941]. Das iranische Feuerheiligtum (I I. Sendschrift del' Deutschen Orient-Gesell $\neg$ schaft), Leipzig.

[40] Stronach, D. [1966]. "The Kuh-i Shahrak Fire Altar", ]NES, 25, 217-217 (=Fire Altar) Stronach, D., Pasargadae. A Report on the Excavations Conducted by the British Institute of Persian Studies from 196 I to 1963, Oxford, 1978.

[41] Shahbazi, A. Sh. [1977]. "From Parsa to Taxt-e jamsid", AMI, N. E 10, 197-207 (=Parsa), hahbazi, A. Sh., "An Achaemenid Symbol, II. Farnah,(God Given) Fortune' Symbolised", AMI, N. E 13, 119-147, 1980.

[42] Herzfeld, E. [1941]. "A history of ancient Persia". Iran in the ancient east. London \& New York, Oxford University Press.

[43] Shenkar, M. [2011]. Temple architecture in the Iranian world in the Hellenistic period in, Anna Kouremenos et al. (eds.), From Pella to Gandhara, hybridization and identity in the art and architecture of the Hellenistic East, BAR int. Series 2221, 117-139.

[44] Tilia, A. B. [1969]. Reconstruction of the Parapet on the Terrace Wall at Persepolis South and West of Palace H, East \&West, N. S. 19, 9-43.

[45] Roaf, M. [1983]. Sculptures and Sculptors at Persepolis (Iran, 2I), London, (=Sculptures) Robert, L., Hellenica. Recueil d'epigraphie, de numismatique et d'antiquites grecques, t, 7, Paris, 1949.

[46] Debevoise, N. C. [1942]. The rock reliefs of ancient Iran. Journal of Near Eastern Studies 1 (1), 76-105.

[47] Hall, J. [2001]. Culture graphic symbols in the art of East and West, translated by R. Behzadi, Tehran.
[48] Bakhtoortash, N. [2005]. Flag of Iran from ancient history to today, Tehran.

[49] Nylander, C. [1983]. "The Standard of the Great King - A Problem in the Alexander Mosaic", OpRom, 14. 2. 19-37.

[50] Frye, R. [1956]. Ancient Heritage, translated by M. rajbnia, Tehran.

[51] Sykes, S. P. [1944]. History of Iran, vol. 1, translated by S. M. Gilani, Tehran.

[52] Poordavud, I. [1966]. Saddle tool, in: Journal of historical studies, vol. 2, 1(7), 29-46.

[53] Mortezavi, M. [1996]. The evolution of weapons in the history of the early Achaemenid period until the end of the Sassanid era, Tarbiat Modares University, Tehran.

[54] vonGall, H. [1974]. "Neue Beobachtungen zu den sog. medischen Felsgrabern", Proceedings of the 2nd Annual Symposium on Archaeological Research in Iran (29th October - rst No $\neg$ vember, 1973), ed. F. Bagherzadeh, Tehran, 139-154.

[55] Cheraghzadeh, S. [2010]. Evolution and its impact on the tomb of the Achaemenid era post, Shiraz.

[56] Dehghan, A. [2011]. The study of religious symbolism in the architecture of Persepolis, Sistan and Baluchestan.

[57] Oshidari, J. [1992]. Zoroastrianism Encyclopedia, Tehran.

[58] Roaf, M. [1995]. Arts Achaemenid art in Iran, translated by P. Marzban, Tehran.

[59] Pope, A. [2008]. Persian architecture, translated by K., Afsar, Tehran.

[60] Haerinck, E. and B. Overlaet, [2008]. Altar shrines and fire altars? architectural rpresentations on Frataraka coinage. Iranica Antiqua 43, 207-233.

[61] Bank Sepah Coin Museum.

[62] AmiriNezhad, A. [2016]. A Research on the Religious and Political Symbols of Coins From the Early Local Dynasty of Persia's kings, in: Biannual Research Journal of Iran Local Histories, 4(2), 121-132.

[63] Iran Money Museum. 